\title{
SUPERFUND, HEDONICS, AND THE SCALES OF ENVIRONMENTAL JUSTICE
}

\author{
Douglas S. Noonan* \\ Associate Professor \\ School of Public Policy \\ Georgia Institute of Technology \\ Atlanta, GA 30332-0345 \\ Phone: 404-385-4257 \\ Fax: 404-385-0504 \\ Douglas.Noonan@pubpolicy.gatech.edu \\ * primary contact author \\ Rama Mohana R. Turaga \\ Thayer School of Engineering \\ Dartmouth College \\ Brett M. Baden \\ Chicago Metropolitan Agency for Planning
}

Final version published as:

Noonan, D. S., Turaga, R. M. R., \& Baden, B. M. (2009). Superfund, Hedonics, and the Scales of Environmental Justice. Environmental Management, 44(5), 909-920. doi:10.1007/s00267009-9372-y 


\section{Bio Statement}

\section{Douglas S. Noonan}

Dr. Noonan is an Associate Professor in the School of Public Policy at the Georgia Institute of Technology. He received his Ph.D. in Public Policy from the University of Chicago, specializing in environmental and urban economics. His current research interests focus on nonmarket valuation of urban amenities, such as air quality and parks, and migration induced by environmental change.

\section{Rama Mohana Turaga}

Dr. Turaga is a research associate in the Thayer School of Engineering at Dartmouth College. He specializes in environmental economics and policy, with particular interests in air quality modeling, risk analysis, and environmental justice. His dissertation models the effects of more spatially refined regulations on "hot spots" in the context of airborne toxics.

\section{Brett M. Baden}

Dr. Baden is a Senior Policy Analyst at the Chicago Metropolitan Agency for Planning. He received his Ph.D. in Public Policy from the University of Chicago. He taught urban and environmental economics at Tufts University and New Jersey Institute of Technology and worked as a consultant on numerous valuation projects. This research was completed prior to his joining Chicago Metropolitan Agency for Planning and does not reflect the views or opinions of that organization. 


\title{
Superfund, Hedonics, and the Scales of Environmental Justice
}

\begin{abstract}
:
Environmental justice (EJ) is prominent in environmental policy, yet EJ research is plagued by debates over methodological procedures. A well-established economic approach, the hedonic price method, can offer guidance on one contentious aspect of EJ research: the choice of the spatial unit of analysis. Environmental managers charged with preventing or remedying inequities grapple with these framing problems. This paper reviews the theoretical and empirical literature on unit choice in EJ, as well as research employing hedonic pricing to assess the spatial extent of hazardous waste site impacts. The insights from hedonics are demonstrated in a series of EJ analyses for a national inventory of Superfund sites. First, as evidence of injustice exhibits substantial sensitivity to the choice of spatial unit, hedonics suggests some units conform better to Superfund impacts than others. Second, hedonic estimates for a particular site can inform the design of appropriate tests of environmental inequity for that site. Implications for policymakers and practitioners of EJ analyses are discussed.
\end{abstract}




\section{Superfund, Hedonics, and the Scales of Environmental Justice}

\section{Introduction}

The environmental justice (EJ) movement now occupies a prominent position in environmental policy. EJ is a core principle for thousands of grassroots environmental organizations, is the subject of a Presidential executive order and an office in the EPA, and recently served to frame how the nation viewed the tragic aftermath of Hurricane Katrina. This paper contributes to the research on environmental equity by (a) proposing a solution, which incorporates results from a well-established economic method, to an important problem in EJ analysis: the choice of the unit of analysis, and (b) presenting new evidence on the distributional equity of Superfund site locations at multiple units of analysis. It offers a pragmatic approach to the modeling choices faced by many practitioners of EJ research, especially when sophisticated environmental modeling proves too costly.

Choosing the correct spatial unit for analysis continues to vex empirical EJ researchers. This problem is amplified among policymakers. State policymakers have found it difficult to identify communities at risk because there is little consistent guidance on how to do so, and US EPA provides limited guidance (Eady 2003). The National Environmental Justice Advisory Council suggests using Census tracts for construction of pollution burden matrices, because tract level data are readily available (NEJAC 2004). Yet data availability may not coincide with optimal unit of analysis as it fails to address critical methodological problems inherent in spatial analyses.

The modifiable areal unit problem (MAUP), often simplified as a matter of aggregation bias, has resisted solutions to date. The approach taken here turns to the well-established hedonic price literature as one way to identify appropriate units of analysis. Linking these two 
literatures holds the promise of practically addressing one of the larger obstacles to advancing empirical EJ claims. The hedonic price model, described in detail by Palmquist and Smith (2002), refers to a statistical relationship between the price of a multiattribute good (e.g., homes, cars) and its attributes. For housing prices, relevant home characteristics includes its structural features, neighborhood quality, and other aspects of its location. The utility of hedonic analyses

for EJ research is demonstrated on a comprehensive, nationwide dataset of Superfund sites at four geographic units. A procedure for practitioners to use hedonic analysis to select the appropriate spatial unit for EJ analysis is outlined. The results contribute to the EJ literature by performing multi-unit analyses at the national scale as well as focused on a specific site.

\section{Literature Review on Scale in EJ}

EJ research is inextricably linked to matters of space and spatial aggregation. From the earliest studies, which found evidence of injustice at county (US GAO 1983) and zip code (United Church of Christ 1987) units but later failed to find similar evidence at tract level (Anderton et. al. 1994, Davidson and Anderton 2000), the critical role of the choice of the unit of analysis became apparent. Since then, numerous studies have explicitly acknowledged the importance of the choice of unit of analysis and sought to address it. The variation in evidence for EJ as a function of the choice of unit of analysis is related to the concept of the modifiable areal unit problem (MAUP). MAUP has been well recognized in the field of geographic analysis although it remains widely under- appreciated in many empirical applications of social science.

Modifiable Areal Unit Problem 
MAUP involves the choice of the proper geographic unit with which to analyze aggregate data. The "modifiable" part refers to the possibility of choosing alternative real units to analyze the same phenomena. For example, average household income could be measured for counties, voting precincts, watersheds, or other areal units. As Jelinski and Wu (1996) outline, the MAUP can be decomposed into two parts. First, the scale component refers to the spatial resolution of the units, where usually smaller units can be combined to form the larger, aggregated geographic unit. The scale choice can influence the observed variance in the phenomenon (e.g., income). When analyzing a given region where a stochastic data generating process gives rise to the individual characteristics, reducing the spatial scale (i.e., increasing the resolution) of analysis effectively increases the sample size and can reduce the observed variance. Unless there is strong spatial clustering, analyses with larger units will tend to have smaller variances as the aggregated means regress toward a global mean. Yet spatial clustering is common for demographics and for some environmental disamenities.

The second component of the MAUP, zoning, refers to how a region is divided into areal sub-units, where unit boundaries may be drawn in such a way that they tend to contain correlated values. In this sense, the zoning component shares much with gerrymandering. Unfortunately, the effects of alternative boundaries on statistical analyses are impossible predict in general as they depend on both the underlying distribution of the characteristics being measured and on the method of boundary-setting. Generally, the zoning component of the MAUP can be expected to affect the observed variance in the areal unit values (e.g., average income). Drawing zones around similar (dissimilar) values can exaggerate (mask) the observed variance. The contentious debates surrounding boundary-drawing in modern society and the strong spatial clustering of (sub)populations suggests that zoning concerns merit some attention. 
In terms of predicting the effects of MAUP when analyzing statistical relationships, there appear to be some regularities in univariate and bivariate settings, though no formal theory has been developed (Jelinski and Wu, 1996). For example, Fotheringham and Wong (1991) note that, in a bivariate analysis, correlations should rise with the scale of aggregation, given stable covariance. Any such regularities are not extant in multivariate analysis, however.

Fotheringham and Wong (1991) provide a review of research on the multivariate MAUP problem, attempt to calibrate linear and logistic regressions with various areal manipulations, and conclude "...the effects of the MAUP in multivariate analysis, unlike those in univariate and bivariate analysis, are essentially unpredictable.” They suggest analysis of multivariate results at varying areal scales in different substantive applications, in order to determine the least variant areal unit appropriate to the field of study.

\section{MAUP and EJ}

In the context of environmental justice, researchers confront aspects of MAUP when choosing the unit of analysis. The basic research question posed by most EJ studies tends to resemble the following: Are environmental conditions worse (are risks higher, is enforcement laxer, etc.) for certain types of people? Operationalizing this question is no straightforward matter, however, and researchers have taken many different paths (see Mennis 2002 for additional discussion). Perhaps the most common approach involves multivariate regression frameworks where the dependent variable, some measure of environmental conditions in a geographic area, is predicted using demographic, political, and economic variables for that area (see discussion and examples in Mohai and Saha 2006). Such an approach, using geographic 
areas as the unit of observation, is made easy by the recent prevalence of demographic and environmental data aggregated to Census boundaries.

Often, the choice of spatial unit of analysis in EJ research is either driven by data availability or not explicitly justified by the authors. In some cases, EJ researchers simply assert what unit is appropriate. Spatial units range from Census blocks (e.g., Chakraborty and others 1999) to counties (e.g., Earnhart 2004) and many resolutions in between (e.g., Pollock and Vittas 1995, Been and Gupta 1997, Taquino and others 2002, Yandle and Burton 1996, Baden and Coursey 2002, Anderton and others 1994, Hockman and Morris 1998). The researcher's choice of geographic area, however, opens the findings to critiques of arbitrariness or worse (Sui 1999, Bowen and Wells 2002, McMaster and others 2002, Kurtz 2003, Glickman 2004, Baden and others 2007).

Currently there is little theoretical or conceptual guidance in identifying the correct unit of analysis and some contend that it may not even be possible (Anderton and others 1994). Not surprisingly then, consensus is lacking in the literature for a single, clear definition of the relevant unit of analysis. Some authors resort to intuition or theory to express their preferences for unit choices or predictions about the effects of the choice of spatial unit (e.g., Cutter and others 1996, McMaster and others 1997, Hockman and Morris 1998, Sui 1999, Bowen 2001, Mantaay 2002). Ringquist (2005) sees unit of analysis largely as a matter of aggregation bias associated with larger units of analysis, where injustice effects should appear stronger at lower resolution. On the other hand, Dolinoy and Miranda (2004) express the intuition that higher resolution predicts higher exposure concentrations. Sui (1999) predicts ambiguous effects of scale on evidence of injustice due to the MAUP, muddying the conventional wisdom somewhat here. 
As an empirical matter, several studies have conducted EJ studies at multiple units to find evidence for the effect of the choice of unit of analysis. Using multiple units for the same scale (in space and time), and the same statistical methods, allows the sensitivity of results to be directly measured. For examples of this research, see Anderton and others (1994), Glickman (1994, 2004), Bowen and others (1995), Cutter and others (1996), Sui (1999), Sheppard and others (1999), Taquino and others (2002), Dolinoy and Miranda (2004), and Baden and others (2007). In his meta-analysis of EJ studies, Ringquist (2005) identifies unit choice as a major source of contention in the literature; his analysis, however, finds little evidence of systematic aggregation bias. In total, even if the conventional wisdom is that effects get stronger as scale of aggregation increases, the empirical evidence on the matter is quite mixed. Further, few studies conducted at multiple units employ consistent methods across the units of analysis and thus fail to provide a reliable evidence for the effect of unit choice (an exception to this is Baden and others 2004). Overall, our review suggests that the choice of unit of analysis is a contentious issue in EJ and a conceptual basis for choosing the unit of analysis will benefit the researchers as well as the practitioners.

\section{Literature Review on Hedonics and NPL}

As studies that employ environmental modeling to spatially portray environmental conditions in greater detail are growing more popular in the EJ literature, this paper proposes a different approach. Rather than rely on sophisticated and often complex models of environmental transport or plumes, market data can provide alternative measures of the spatial extent of environmental disamenities. We recommend the application of the hedonic price 
method, a well-established approach to environmental valuation, as a basis for choosing the spatial unit for EJ analysis.

Hedonic Price Method and the Spatial Extent of Impact for EJ Analysis

The hedonic price method utilizes the variation in house prices with variation in housing attributes (e.g., lot size, number of bed rooms, distance to an amenity, etc.) to statistically infer the implicit price of any particular attribute. It is commonly used in natural resource damage assessment and other policy and legal settings (Palmquist and Smith 2002). In environmental applications, the attribute of interest is some measure of environmental quality near the property. Thus, for example, for an environmental disamenity such as a hazardous waste site, the distance of the property from the site is treated as a proxy for environmental quality; that is, the environmental quality gets better as one moves away from the site. Accordingly, one would expect that the closer a house is to a hazardous waste site, the lower its price, all else being equal. Thus the hedonic price method hypothesizes that property markets reflect the impact of environmental disamenities via sales prices.

Such market representations of impacts may not match perfectly with more strictly geophysical environmental models. Yet they should capture at least the risks as perceived by residents (i.e., those possibly suffering from the injustice) rather than risks as estimated in an expert's assessment. Moreover, price effects can capture many impacts of a particular disamenity, including aesthetics, congestion, or other attributes not included in a strictly geophysical model. Although several studies find different hedonic and non-hedonic valuations of environmental problems, there is a substantial body of work that shows hedonics perform well at measuring popular perceptions. The economic literature has many comparisons of values 
from housing market prices to those from external sources like risk assessments or engineering studies. Most notably, Gayer and others $(2000,2002)$ find that a housing market reflects Superfund sites' risks quite accurately after the EPA releases its remedial investigation and after improved information about sites. Other applications also find substantial similarity between hedonic values and those from risk analyses (Davis 2004), surveys (Chattopadhyay and others 2005, Hite 2009, D’Arge and Shogren 1989), and other damage estimates (Brookshire and others 1985, Hallstrom and Smith 2005).

Of course, there are limits to the inferences that can be drawn from property price data. Market data may poorly reflect the relevant interests. The market price approach relies heavily on the harms perceived by residents, a potential weakness if risks aren’t capitalized. There may be important market failures, like asymmetric information yielding misleading prices. Information surely plays a crucial role. For example, if Hispanics lack information, perhaps due to language barriers, market prices might not accurately reflect a hazard's impact. The reality is that great uncertainty clouds many hazards, markets may reflect or distort that uncertainty even as epidemiologists and other experts struggle with complex situations. There may also be biases in the statistical analysis of the hedonics. Modeling concerns like omitted variables, sample selection bias, and spatial autocorrelation (see, e.g., Anselin and Lozano-Gracia 2008) are generally also present with alternative approaches, and often epidemiological/fate-and-transport models face even greater challenges. Property markets provide a measure of the perceived impacts even when there is significant scientific uncertainty. Property markets need not have the final word; they are just one measure. 
Hedonics and NPL Sites

For many environmental hazards, numerous hedonic price studies have revealed considerable information about the spatial extent of impact. Hedonics employs statistical analyses to identify how much variation in sales prices are attributable to different features of the property (e.g., lot size, number of rooms, distance to an amenity). Price effects have been measured for environmental disamenities commonly discussed in the EJ literature, such as landfills (e.g., Hite 2009, Hite and others 2001, Nelson and others 1992), TSDFs / RCRA sites (Thayer and others 1992), and air quality (Smith and Huang 1995; Boyle and others 2001, Smith and others 2004). This paper explores another area popular in both EJ and hedonic literatures: Superfund National Priorities List (NPL) sites.

[Table 1 here]

Of interest here are studies that identify when the price effects of proximity to NPL (or other hazardous) sites fade to zero. Table 1 reviews 14 studies that use the hedonic price method to measure the effect on property prices of distance to an NPL or other hazardous waste site. Table 1 reports the hazard(s) studied and, for NPL sites only, environmental media through which the risks are transmitted. The EPA tracks the contaminated media for NPL sites, whether it is air (A), water (W), soil (S), other (O), or some combination (EPA 2003). Most sites have multiple contamination types. Many of these hedonic studies pay close attention to how prices 
reflect changes in site status (e.g., discovery, listing, remediation, de-listing). They provide evidence that prices capture a site’s changing impacts over time as changes in status are associated with changes in prices. Although many of the studies reviewed are concerned with the timing of information flows and consumer responses, for purposes of comparability, only distance effects for periods when the presence of a site is clearly recognized are reported. Table 1 also reports the maximum distance at which the site(s) affects property values, and whether that distance is derived or assumed. Most effects were found to dissipate within 2-5 miles; all results find price effects are indistinct after 6 miles.

\section{Data and Methods}

To demonstrate the usefulness of the hedonic approach to defining the unit of analysis, this paper conducts numerous conventional or "classic" (Mohai and Saha 2006) EJ studies for NPL sites. This is done in two parts. The first is a set of multivariate statistical analyses of patterns in demographics and Superfund sites nationwide (of particular interest to academic EJ researchers). The second part demonstrates an EJ analysis of a single site (of particular interest to practitioners and managers doing an EJ study). In both parts, the hypothesis is that evidence of injustice is sensitive to the choice of the unit of analysis. In addition, in the appendix, this paper identifies systematic patterns in this sensitivity as the characteristics of the hazard vary. This tests the hypothesis that hazards typically associated with larger spatial impacts (i.e., larger “footprints”) tend to exhibit more unjust localities at different units than more spatially confined hazards. The appendix reports estimates of the classic EJ approach at different spatial units for different types of NPL sites - showing whether sites with larger "footprints" (e.g., air pollution impacts) tend to show stronger evidence of injustice at larger units. 
First, a conventional empirical EJ model is developed here. This lends comparability between our findings and those prevalent in the EJ literature. This analysis seeks to identify the sensitivity of commonly reported EJ evidence to the choice of the unit of analysis and then to demonstrate how that sensitivity relates to the spatial extent of impacts as measured through property markets.

A logit model predicts the presence of a site using several covariates standard in the EJ literature. The dependent variable equals 1 if there is at least one site listed on the NPL as of the year 2002 in the areal unit, and 0 otherwise. Similar approaches can be found in Anderton and others (1994), Been (1995), and Cutter and others (1996), among others. The variable definitions and their summary statistics are in table 2. The variables of interest (percent black, percent Hispanic, and median household income) capture three forms of injustice. Environmental racism or inequity for the poor can be identified if the coefficients for these variables are found to be significant and positive or negative, respectively. All demographic variables are from the 2000 U.S. Census and include the entire United States. The control group is thus all geographic units not hosting an NPL site.

[Table 2 here]

Identical analyses were performed at each of four different spatial units: county, zip code, tract, and block group. Table 2 shows descriptive statistics for the variables across different units. All models include state-level fixed and random effects. The logit models were also 
estimated for subsamples of the NPL sites based on the media of their contamination. Dummy variables for four categories of contaminant media are constructed as air, water, soil, and other. Separate logit models for each media type can be interpreted as estimating the location-specific demographic characteristics for each type of NPL site. In this way, unjust siting conditions for different types of sites can be observed at different spatial units.

\section{Results}

\section{Sensitivity of EJ Evidence to the Choice of Unit of Analysis}

The results of the full sample logit models are summarized in table 3 . The results are broadly consistent with the existing EJ literature. Most of the non-justice variables show fairly consistent effects across spatial units. The results for unemployment, however, are positive and significant only at the block-group level.

[Table 3 here]

NPL sites are not distributed randomly with respect to demographics. Areas with greater proportions of blacks are more likely to have an NPL site, at all units considered here. Greater proportions of Hispanics are also positively associated with NPL site locations, but only at the smaller units. Counties hosting NPL sites tend to have smaller proportions of Hispanics. Perhaps most interestingly, poorer areas are more likely to have NPL sites when those areas are small (i.e., tracts or block groups), but richer areas are more likely to have NPL sites when the 
unit is large. Such a result resembles the doughnut-style economic development described in Anderton and others (1994). Overall, across the different units of analysis, the evidence of justice is mixed. For blacks, the evidence points to consistent injustice. For Hispanics, however, the evidence switches across units, demonstrating both justice and reverse injustice depending on the unit chosen for analysis. And, for the poor, the evidence points to injustice only at some spatial units.

The appendix reports an analysis of NPL sites separately, differentiated by the nature of the pollutant media. Overall, the evidence of injustice for particular types of NPL sites is roughly comparable to the evidence of injustice across all NPL sites.

The sensitivity of some of the evidence to spatial unit is particularly interesting in light of the conclusions of previous research. For NPL sites in the U.S., the pattern in table 3 contradicts the conventional wisdom among many geographers and others in the EJ field (e.g., Cutter and others 1996, Ringquist 2005) that injustice is more easily observed at larger units. Table 3 indicates the strongest evidence of injustice at the block group and tract scales, weakening and sometimes even reversing at the larger units.

The sensitivity of the results to the unit of analysis highlights the importance of the researcher's choice of spatial unit. The hedonic literature on NPL and hazardous waste can guide the selection of the appropriate unit, however. Most studies identify that price effects of proximity to hazardous waste sites dissipate within 2-5 miles. Although there is noticeable noise in this estimate, a typical impact radius of more than a few miles points to an appropriate unit somewhat larger than most tracts and smaller than most counties for a nationwide study of Superfund sites. This follows Glickman (2004) and Ringquist's (2005) recommendation to somehow match researchers' definitions of community to the actual area of environmental 
impact. Yet picking an aggregated unit (e.g., zip codes) to match a uniform, typical impact size for the hazard encounters problems when the aggregated units vary widely and systematically in size. Mohai and Saha (2006) offer an excellent way to deal with this problem - defining disaggregated units as proximate if more than half of their area lies in the impact zone. Thus, table 3 reports a fifth logit analysis, where block groups are considered NPL hosts if at least 50\% of their area is within 6 miles of a site. (Six miles represents the upper limit of impact zones from the literature in table 1, likely yielding conservative coefficient estimates.) The mixed results reinforce the sensitivity to unit choice and inconsistency, where minority and rich communities are less likely to host. Where results are sensitive to unit choice, the hedonic values offer guidance (with justification) for a practitioner looking to choose a spatial unit for analysis.

\section{A Procedure for Using Hedonics to Inform a Single-Site EJ Assessment}

Up to this point, the hedonics estimates suggested a spatial extent of impact typical of NPL sites, and this recommended a spatial unit of analysis for a conventional EJ study for a broad class of sites. Practitioners, however, are often required to analyze EJ evidence for a particular site. Hedonics estimates can also identify any one site's geographic area of impact. This may be most appropriate, considering the great heterogeneity across NPL sites (Kiel and Williams 2007). This alternative method uses hedonics to evaluate the extent to which residents suffer from the disamenity. Hedonic estimates can identify the spatial extent of a site's impact on property values and even the impact severity. Such information allows equity comparisons. For example, if hedonics reveals that a site's impact dissipates after five miles, a sample of observations taken inside and outside this region enables tests of environmental equity. Sampling smaller geographic units (e.g., block groups) should more closely correspond to the 
estimated impact zone. A comparison of observations inside the hedonics-identified impacted area with those outside presents a much more accurate EJ comparison than the usual reliance on demographic differences in host block groups, tracts, etc. Plus, unlike geophysical models, such hedonic analyses are often available to the researcher at low cost.

This section outlines a procedure for practitioners to identify the appropriate spatial bounds for an EJ analysis when the analysis is focused on any one particular site. Mapping the nuisance in some GIS facilitates analysis. The procedure described employs Census data for convenience; other data and areal units can be used in other contexts.

1. Search for existing hedonic studies, published or not, on the site. If found, skip to step 6 if possible.

2. Collect and map demographic data at multiple census units, especially small units (e.g., block groups). Census data linked to Census areal units are readily available from the US Census Bureau; intercensal years may require estimation or alternative data sources.

3. Obtain and map housing value data - including property characteristics (e.g., number of bedrooms, lot size, etc.) and sale prices (ideally) or assessed value. Rich geographic data describing properties' neighborhoods are also critical. Of course, distance of each property to the site must be measured. The extensive availability of GIS tools has made distance measurement a fairly straightforward exercise.

4. Conduct hedonic price analysis. Consult an expert or see texts like Freeman (1993) and excellent examples like those papers in table 1 and Noonan and others (2007). Essentially the task is to regress housing values on housing and neighborhood characteristics (as control variables) and the distance to the local environmental hazard. 
5. Test for robustness of hedonic estimation to second-order spatial effects or for spatially autocorrelated errors. Spatial autocorrelation arises when the statistical noise in (price) predictions tends to cluster geographically. A fully specified hedonic price function may not exhibit spatial autocorrelation, but spatially correlated unobservables may require advanced spatial econometric techniques to avoid potential bias (see, e.g., Anselin and Lozano-Gracia, 2008; Kim and others, 2003). Careful hedonic (and EJ) analyses should take care to make statistical inferences robust to spatial dependence in the data.

6. Identify where proximity to site no longer affect price. Special attention must be made to identify when the coefficient of distance-to-site variable (i.e., the slope of the price gradient or "marginal price" of distance) becomes 0 - or when distance no longer corresponds to price. This can be done a number of ways, such as via careful functional form specification (e.g., discontinuities, spline functions). A simple method is to use discrete "distance bands" and observe where their effects vanish.

7. Let the spatial zone of impact identified in step 6 inform the EJ analysis. Simply divide the region into two groups, those whose housing values are affected by nearness to the site and everyone else. This approach will identify the appropriate spatial extent for EJ analysis, and will also provide the ancillary benefit of generating information about the extent of perceived effect for the environmental hazard. Equity can be assessed by statistically testing the difference in mean values of the EJ variables (race and income) within and outside the impact zone. First, it should be emphasized here that identifying who are within and who are outside the impact zone is often not straightforward, given the nature of spatial aggregation of census data. EJ studies use several approaches to identifying the census units that fall within a particular impact zone around a waste site (see Mennis, 2002 for details of different approaches used in EJ literature). 
A complex and more accurate method is called dasymetric mapping (Mennis, 2002; Boone, 2008) in which land use maps are used to delineate the areas where population live within a census unit. The second issue here is identifying the comparison group, i.e., the question of who lives outside the impact zone. The results of EJ analysis are likely to vary depending on whether one chooses the rest of the county, MSA, or state as the comparison group and currently there is little consensus on or theoretical guidance for this choice.

\section{A Demonstration}

This alternative approach is demonstrated using results of Kolhase's (1991) study of properties around the South Cavalcade St NPL site in Harris County, TX. This represents finding a study in step 1 and then proceeding to step 6 . This example is selected only for convenience (a readily available study).

The South Cavalcade site was a 66-acre wood treatment plant near downtown Houston that operated from 1910-1962 and was listed on the NPL in 1986. Constructing a buffer of 4.76 miles around the NPL site, the distance threshold identified by Kohlhase (1991) for that site, allows for a test of the difference in means of EJ variables (i.e., percent black, percent Hispanic, and median income) inside and outside of this buffer. This analysis is conducted at both Census tract and Census block group units within Harris County because smaller units can better match the 4.76-mile buffer. The rest of the county serves as the comparison group.

Evidence at both units of analysis for all three variables suggests environmental inequities around South Cavalcade NPL site. For instance, the mean percent black in block groups or tracts within the buffer is 11.7 percent or 12.5 percent, respectively, greater than elsewhere in the county. Median household incomes are \$21,000 lower inside the buffer than 
outside. Using a logit model, the likelihood of a block group or tract being inside the buffer is positively associated with percent minority and negatively associated with income. The results for the difference in means and for the logit analysis all point to significant evidence of environmental injustice (except for percent black at tract level). The results are presented in table 4. Obviously, making causal inferences about the source of the inequity is problematic, especially in light of this site’s early establishment.

[Table 4 here]

\section{Discussion}

Evidence of environmental injustice varies substantially across geographic units. Table 3 depicts this inconsistency for NPL sites nationwide. While theories of environmental justice provide limited guidance on the proper geographic unit, data limitations make an ideal solution unlikely, especially using the geography developed by the Census.

Hedonic analyses of property markets may help researchers address this problem by identifying appropriate geographic bounds. A thorough review of the hedonic literature shows that NPL and other hazardous sites’ impacts typically extend no more than 6 miles away from the site. Their impact zone appears larger than tracts or block groups, yet smaller than counties. This 6-mile buffer identified in the hedonics can inform the areal concentration approach (Mohai and Saha 2006) for conducting a conventional EJ study for the Superfund program facilities. Furthermore, if the spatial impact zone of an NPL site is related to the media that it 
contaminates, one might reasonably use different scales for different types of sites in conventional EJ analyses. The analysis, summarized in the appendix, shows that the evidence of environmental inequity differs only somewhat across media types.

This paper has reviewed the intractability and confusion arising due to the MAUP in the context of environmental justice. Political and legal imperatives will continue to demand EJ analyses despite these challenges. This paper proposes that a well-established economic method, the hedonic price method, offers useful guidance to policymakers and researchers in conducting an original EJ analysis. The hedonic literature for many kinds of disamenities can be used to inform the choice of spatial unit and geographic scale in environmental justice studies. It helps researchers avoid seemingly arbitrary unit choice. It adds to the validity of the researchers' choice by relying on the revealed preference of those most affected by the disamenity (i.e., residents). Such an approach might inform the choice of the zip code scale or, better still, the areal concentration approach for an analysis such as in table 3. For the large-N studies of entire classes of disamenities (e.g., all NPL sites) common to academic research, the approach used here can help objectively and transparently identify an "appropriate" impact zone. This could go a long way towards defusing some of the threat posed by the MAUP in the EJ literature. The results in table 3, once the county model is dropped because counties are too large, point to considerable consistency across the different scales of the unit of analysis.

EJ analysis for specific sites, which the practitioners (e.g., administrators and government analysts) often encounter, could also benefit from the proposed hedonic approach to choosing the appropriate spatial area for analysis. Results of a hedonic analysis can instruct the design of appropriate tests of injustice. This approach is demonstrated in table 4 using results from a hedonic analysis of the South Cavalcade NPL site in Harris County, TX to help identify which 
residents are in the impact zone of the hazard and those who are not. At least with respect to this site, the evidence strongly supports the existence of environmental inequities.

This analysis suggests an approach generalizable across environmental policy contexts. Given the technological advances in statistical and GIS software and the increasing availability of demographic data in many cities, hedonic analyses are becoming easier to perform. To properly calibrate an EJ study, thereby blunting criticisms of arbitrariness or bias, a policy analyst could estimate a simple hedonic regression to determine the extent of the spillover effects of a disamenity on property values. This information can then guide an investigation of the extent of environmental injustice. A feasible and broadly applicable step-by-step procedure is outlined here. Of course, other approaches may also be available.

Before we conclude, a few caveats regarding the approach proposed here need reemphasis. First, the hedonic approach is only one possible approach to identifying the spatial extent of the environmental impact of disamenities. As explained earlier, a number of issues such as information asymmetries and statistical biases could influence the results of hedonic analysis. Thus we view our approach more as a complement than a substitute for the more sophisticated, but often complex, environmental fate and transport models. Still, we maintain that the hedonic approach offers an improvement over arbitrary or less-transparent methods for identifying spatial "footprints" of sites. Second, from a practitioner perspective, conducting an original hedonic analysis (when published reports are not readily available) is perhaps not an easy task, especially a state-of-the-art hedonic model. While the hedonic analysis is not as complex as most fate and transport models, hedonic analyses could still overburden the technical resources available at local and state governments. Finally, the approach presented here solves only part of the EJ analysis puzzle. At least two other aspects of conventional EJ analysis still 
require some resolution. One is choosing the appropriate geographic area to compare against when testing whether some population groups are more concentrated within the impact zone than others. The other aspect is choosing the control variables in the logistic regressions that predict the probability of finding a hazard within a census unit. The choice of control variables determines the counterfactual state and the EJ results are potentially sensitive to this choice (Noonan, 2008). Just as advanced spatial regression techniques can affect hedonic results, spatial econometrics can alter findings of EJ analyses (e.g., Pastor and others 2004, Grineski and Collins 2008).

\section{Conclusions}

Public agencies are often faced with the difficult task of conducting objective analyses of complex problems, and EJ is surely no exception. Heated debate surrounds the use of empirical evidence on this topic. Up to this point, surprisingly little practical guidance has been offered to agency officials, planners, or policy advocates, seeking to produce objective, valid measures of environmental justice. This paper marks a step in this direction. It suggests that the mountain of hedonic research produced by urban and real estate economists can be used to craft more robust EJ studies. The hedonic approach lets behavior in housing markets indicate the scale and scope

of a hazardous facility's impact. While the hedonic method may not capture the spatial extent of the full range of impacts associated with the environmental disamenities, this approach at least provides a transparent basis for choosing the spatial area of analysis in conventional EJ studies.

\section{Acknowledgments}


Partial support for this study was provided by the National Science Foundation program in Human Spatial Dynamics for the grant 'Spatial bounding in Mental and Geophysical Models’ (\# SES-0433165).

\section{References}

Anderton DL, Anderson AB, Rossi PH, Oakes JM, Fraser MR (1994) Environmental Equity: The Demographics of Dumping. Demography 31(2): 229-248

Anselin L, Lozano-Gracia N (2008) Errors in Variables and Spatial Effects in Hedonic House Price Models of Ambient Air Quality. Empirical Economics 34: 5-34

Baden B, Coursey D (2002) The Locality of Waste Sites within the City of Chicago: A Demographic, Social, and Economic Analysis. Resource and Energy Economics 24: 5393

Baden B, Noonan DS, and Turaga RMR (2007) Scales of Justice: Is there A Geographic Bias in Environmental Equity Analysis? Journal of Environmental Planning and Management 50(2): 163-185

Been V (1995) Analyzing Evidence of Environmental Justice. Journal of Land Use and Environmental Law 11: 1-36

Been V, Gupta F (1997) Coming to the Nuisance or Going to the Barrios? A Longitudinal Analysis of Environmental Justice Claims. Ecology Law Quarterly 24(1): 1-56

Boone CG (2008) Improving Resolution of Census Data in Metropolitan Areas Using a Dasymetric Approach: Applications for the Baltimore Ecosystem Study. Cities and the Environment 1(1): article 3, 25 pp 
Bowen WM (2001) Environmental Justice through Research-based Decision Making. Garland Publishing, New York

Bowen WM, Wells MV (2002) The Politics and Reality of Environmental Justice: A History and Considerations for Public Administrators and Policy Makers. Public Administration Review 62(6): 688-698

Bowen WM, Salling MJ, Haynes KE, Cyran EJ (1995) Toward Environmental Justice, Spatial Equity in Ohio and Cleveland. Annals of the Association of American Geographers 84(4): 641-663

Boyle M, Kiel KA (2001) A Survey of House Price Hedonic Studies of the Impact of Environmental Externalities. Journal of Real Estate Literature 9(2): 117-144

Brookshire DS, Thayer MA, Tschirhart J, Schulze WD (1985) A Test of the Expected Utility Model: Evidence from Earthquake Risks. Journal of Political Economy 93(2): 369-389

Chakraborty J, Fokenbrock DJ, Schweitzer LA (1999) Using GIS to Assess the Environmental Justice Consequences of Transportation System Changes. Transactions in GIS 3(3): 239258

Chattopadhyay S, Braden JB, Patunuru A (2005) Benefits of Hazardous Waste Cleanup: New Evidence from Survey- and Market-Based Property Value Approaches. Contemporary Economic Policy 23(3): 357-375

Cutter SL, Holm D, Clark L (1996) The Role of Geographic Scale in Monitoring Environmental Justice. Risk Analysis 16(4): 517-526

D’Arge RC, Shogren JF (1989) Non-Market Asset Prices: A Comparison of Three Valuation Approaches. In: Folmer H, Van Ierland E (ed). Valuation Methods and Policy Making in Environmental Economics. Elsevier Science, New York, pp 16-36 
Dale L, Murdoch JC, Thayer MA, Waddell PA (1999) Do Property Values Rebound from Environmental Stigmas? Evidence from Dallas. Land Economics 75(2): 311-326

Davidson P, Anderton DL (2000) Demographics of Dumping II: A National Environmental Equity Survey and the Distribution of Hazardous Materials Handlers. Demography 37(4): 461-466

Davis LW (2004) The Effect of Health Risk on Housing Values: Evidence from a Cancer Cluster. American Economic Review 94(5): 1693-1704

Deaton JB, Hoehn JP (2004) Hedonic Analysis of Hazardous Waste Sites in the Presence of Other Urban Disamenities. Environmental Science \& Policy 7: 499-508

Dolinoy DC, Miranda L (2004) GIS Modeling of Air Toxics Releases from TRI-Reporting and Non-TRI-Reporting Facilities: Impacts for Environmental Justice. Environmental Health Perspectives 112(17): 1717-1724

Eady V (2003) Environmental Justice in State Policy Decisions. In: Julian A, Bullard RD, Evans B (ed). Just Sustainabilities: Development in an Unequal World. MIT Press, Cambridge Earnhart D (2004) The Effects of Community Characteristics on Polluter Compliance Levels. Land Economics 80(3): 408-432

EPA (2003) Comprehensive Environmental Response, Compensation and Liability Information System (CERCLIS). Available online at: http://www.epa.gov/superfund/sites/cursites/ Fotheringham AS, Wong DWS (1991) The Modifiable Areal Unit Problem in Multivariate Statistical Analysis. Environment and Planning A 23: 1025-1044

Freeman M III (1993) The Measurement of Environmental and Resource Values. Resources for the Future Press, Washington, DC 
Gayer T, Hamilton JT, Viscusi KW (2000) Private Values of Risk Tradeoffs at Superfund Sites: Housing Market Evidence on Learning about Risk. Review of Economics and Statistics 82(3): 439-451

Gayer T, Hamilton JT, Viscusi KW (2002) The Market Value of Reducing Cancer Risk: Hedonic Housing Prices with Changing Information. Southern Economic Journal 66(2): 266-289

Glickman TS (1994) Measuring Environmental Equity with Geographic Information Systems. Renewable Resources Journal 12(3): 17-21

Glickman TS (2004) Evaluating Environmental Equity in Allegheny County. New York:

Program for the Human Environment, Rockefeller University. Available: http://phe.rockefeller.edu/comm_risk/commrsk3.html [last accessed 14 January 2006]

Michaels RG, Smith VK (1990) Market Segmentation and Valuing Amenities with Hedonic Models: The Case of Hazardous Waste Sites. Journal of Urban Economics 28: 223-242

Grineski, SE, Collins TW (2008) Exploring Patterns of Environmental Injustice in the Global South: Maquiladoras in Ciudad Juarez, Mexico. Population and Environment 29: 247-270 Hallstrom DG, Smith VK (2005) Market Responses to Hurricanes. Journal of Environmental Economics and Management 50(3): 541-561

Hite D (2009) Factors Influencing Differences between Survey and Market-based Environmental Value Measures. Urban Studies 46(1): 117-138

Hite D, Chern W, Hitzhusen F, Randall A (2001) Property Value Impacts of an Environmental Amenity: The Case of Landfills. Journal of Real Estate Finance and Economics 22(2): $185-202$ 
Hockman EM, Morris CM (1998) Progress towards Environmental Justice: A Five-year Perspective of Toxicity, Race, and Poverty in Michigan, 1990-1995. Journal of Environmental Planning and Management 41(2): 157-176

Ihlanfeldt KR, Taylor, LO (2004) Externality Effects of Small-Scale Hazardous Waste Sites: Evidence from Urban Commercial Property Markets. Journal of Environmental Economics and Management 47: 117-139

Jelinski DE, Wu J (1996) The Modifiable Areal Unit Problem and Implications for Landscape Ecology. Landscape Ecology, 11(3):129-140

Kiel KA (1995) Measuring the Impact of the Discovery and Cleaning of Identified Hazardous Waste Sites on House Values. Land Economics 71(4): 428-435

Kiel KA, Williams M (2007) The Impact of Superfund Sites on Local Property Values: Are All Sites the Same? Journal of Urban Economics 61(1): 170-192

Kiel KA, Zabel J (2001) Estimating the Economic Benefits of Cleaning up Superfund Sites: The Case of Woburn, Massachusetts. Journal of Real Estate Finance and Economics 22(2/3): $163-184$

Kim CW, Phipps TT, Anselin L (2003) Measuring the Benefits of Air Quality Improvement: A Spatial Hedonic Approach. Journal of Environmental Economics and Management 45: 24-39

Kohlhase JE (1991) The Impact of Toxic Waste Sites on Housing Values. Journal of Urban Economics 30(1): 1-26

Kurtz HE (2003) Scale Frames and Counter-Scale Frames: Constructing the Problem of Environmental Injustice. Political Geography 22: 887-916 
Maantay J (2002) Mapping Environmental Injustices: Pitfalls and Potential of Geographic Information Systems in Assessing Environmental Health and Equity. Environmental Health Perspectives 110(2): 161-171

McCluskey JJ, Rausser GC (2003) Stigmatized Asset Value: Is it Temporary of Long-Term? Review of Economics and Statistics 85(2): 276-285

McMaster RB, Leitner H, Sheppard E (1997) GIS-Based Environmental Equity and Risk Assessment: Methodological Problems and Prospects. Cartography and Geographic Information Systems 24(3): 172-189

Mennis J (2002) Using Geographic Information Systems to Create and Analyze Statistical Surfaces of Population and Risk for Environmental Justice Analysis. Social Science Quarterly 83(1): 281-297

Mohai P, Saha R (2006) Reassessing Racial and Socioeconomic Disparities in Environmental Justice Research. Demography 43(2): 383-399

National Environmental Justice Advisory Council (2004) Ensuring Risk Reductions in Communities with Multiple Stressors: Environmental Justice and Cumulative Risks/Impacts. December, 2004. Report available online at: http://www.epa.gov/compliance/resources/publications/ej/nejac/nejac-cum-risk-rpt122104.pdf [Last accessed 12 February 2006.]

Nelson AC, Genereux J, Genereux M (1992) Price Effects of Landfills on House Values. Land Economics 68(4): 359-365

Noonan DS (2008). Evidence of Environmental Justice: A Critical Perspective on the Practice of EJ Research and Lessons for Policy Design. Social Science Quarterly 89(5): 1154-1174 
Noonan DS, Krupka DJ, Baden BM (2007) Neighborhood Dynamics and Price Effects of Superfund Sites. Journal of Regional Science 47(4): 685-692

Palmquist RB, Smith VK (2002) The Use of Hedonic Property Value Techniques for Policy and Litigation. In Tietenberg T, and Folmer H (ed). The International Yearbook of Environmental and Resource Economics 2002/2003. Edward Elgar, Cheltenham UK, pp.115-164

Pastor M, Sadd JL, Morello-Frosh R (2004) Waiting to Inhale: The Demographics of Toxic Air Release Facilities in 21st-Century California. Social Science Quarterly 85(2): 420-440 Pollock PH, Vittas EM (1995) Who Bears the Burdens of Environmental Pollution? Race, Ethnicity, and Environmental Equity in Florida. Social Science Quarterly 76(2): 295-310 Ringquist EJ (2005) Assessing Evidence of Environmental Inequities: A Meta-Analysis. Journal of Policy Analysis and Management 24(2): 223-247

Sheppard E, Leitner H, McMaster RB, Tian H (1999) GIS-Based Measures of Environmental Equity: Exploring their Sensitivity and Significance. Journal of Exposure Analysis and Environmental Epidemiology 9: 18-28

Smith VK, Huang J (1995) Can Markets Value Air Quality? A Meta-Analysis of Hedonic Property Value Models. Journal of Political Economy 103(1): 209-227

Smith VK, Sieg H, Banzhaf SH, Walsh RP (2004) General Equilibrium Benefits for Environmental Improvements: Projected Ozone Reductions under EPA’s Prospective Analysis for the Los Angeles Air Basin. Journal of Environmental Economics and Management 47: 559-584 
Smolen GE, Moore G, Conway LV (1992) Economic Effects of Hazardous Chemical and Proposed Radioactive Waste Landfills on Surrounding Real Estate Values. The Journal of Real Estate Research 7(3): 283-295

Sui D (1999) GIS, Environmental Equity, and the Modifiable Areal Unit Problem (MAUP). In: Massimo C, Onsrud H (ed). Geographic Information Research: Transatlantic Perspectives. Taylor and Francis, London

Taquino M, Parisi D, Gill DA (2002) Units of Analysis and the Environmental Justice Hypothesis: The Case of Industrial Hog Farms. Social Science Quarterly 83(1): 298-316

Thayer M, Albers H, Rahmatian M (1992) The Benefits of Reducing Exposure to Waste Disposal Sites: A Hedonic Housing Value Approach. The Journal of Real Estate Research 7(3): 265-282

U.S. General Accounting Office (1983) Siting of Hazardous Waste Landfills and Their Correlation with Racial and Economic Status of Surrounding Communities. US GPO, Washington, DC

United Church of Christ Commission for Racial Justice and Public Data Access, Inc. (1987) Toxic Waste and Race in the United States: A National Report on the Racial and SocioEconomic Characteristics of Communities with Hazardous Waste Sites. United Church of Christ, New York

Yandle T, Burton D (1996) Reexamining Environmental Justice: A Statistical Analysis of Historical Hazardous Waste Landfill Siting Patterns in Metropolitan Texas. Social Science Quarterly 77(3): 477-492

\section{Appendix}


Table 5 provides a summary of additional estimations of logit models that predict the presence of NPL sites by media. Separate estimations are performed for air, for water, for soil, and for other sites. The results are given for the race and income variables only, while the control variables are omitted from the table for brevity.

[Table 5 here]

Table 5 reveals several patterns. For air-polluting NPL sites, injustice appears with respect to race at small units. The sign on the effect of Hispanic changes and becomes significant at the county level. In addition, income is only significant at the tract level. At the largest unit, less Hispanic counties are more likely to have air-related NPL sites. For waterrelated sites, injustice with respect to blacks also appears below the county level, with respect to the poor below the zip code level, and with respect to Hispanics at zip code and tract levels. Soil-related sites are more likely to be found in more black areas (when the area is smaller than county) and in poorer and more Hispanic areas (when the area is smaller than zip codes). The effect of Hispanics, however, reverses at the county level - where Hispanics are less likely to be in counties with water- or soil-polluting NPL sites. For “Other” sites, Black is positively associated with the probability of hosting an NPL site at any unit of analysis. While injustice appears for Hispanics at units below the county level, the results for income are again mixed.

Sites with different contaminants may be expected to have varying spatial impacts. The hedonic literature suggests that the effects of proximity do indeed vary substantially across sites 
(Kiel and Williams 2007), although explaining this variation remains a challenge. If sites with air contaminants have broader impacts, and those with soil contaminants have a more confined impact, how evidence of injustice varies across contaminant types can give at least a crude indication of the pattern of injustice for NPL sites nationwide. For air contaminant sites, the evidence rejects the injustice hypothesis for blacks, Hispanics, and the poor, especially at the county level. If the larger unit is the most appropriate for these sites, the evidence points to disproportionately higher exposure for counties with fewer Hispanics. If these smaller units are most appropriate for soil contaminant sites, it appears that minorities and the poor are disproportionately exposed to these hazards. Overall, logit analyses at small units support the injustice hypothesis, whereas these effects vanish and reverse at larger (county) scales. Interestingly, the results in Table 5 for particular subsets of sites do not differ dramatically from the results for the full set of sites. Assessing injustice by looking at large or small units for only large or small "footprint" sites does not seriously alter the results from all sites as reported in Table 3. 
Table 1: Summary of NPL Spatial Economic Impact Studies

\begin{tabular}{|c|c|c|c|}
\hline Study & Hazard & NPL media type & Max. distance of effect \\
\hline $\begin{array}{l}\text { Michaels and } \\
\text { Smith, } 1990\end{array}$ & $\begin{array}{l}\text { Eleven NPL and non-NPL } \\
\text { sites in suburban Boston }\end{array}$ & Many sites/media & No discussion \\
\hline \multirow{7}{*}{ Kohlhase, 1991} & $\begin{array}{l}\text { Pooled NPL sites in Harris } \\
\text { county, TX }\end{array}$ & Many sites/media & 6.19 miles \\
\hline & Brio Refining Inc & $\mathrm{A}, \mathrm{W}, \mathrm{S}, \mathrm{O}$ & 2.61 miles \\
\hline & Crystal chemical Co & $\mathrm{W}, \mathrm{S}$ & 2.94 miles \\
\hline & Geneva Industries & $\mathrm{W}, \mathrm{S}, \mathrm{O}$ & 1.86 miles \\
\hline & Harris-Farley & $\mathrm{A}, \mathrm{W}, \mathrm{S}$ & 4.87 miles \\
\hline & $\begin{array}{l}\text { Sol-Lynn Industrial } \\
\text { transformers }\end{array}$ & W, S, O & 3.92 miles \\
\hline & South Cavalcade St & $\mathrm{W}, \mathrm{S}$ & 4.76 miles \\
\hline Kiel, 1995 & $\begin{array}{l}\text { Industriplex and W\&G Well, } \\
\text { Woburn, MA }\end{array}$ & $\begin{array}{l}\text { Industriplex: A, W, S } \\
\text { W\&G Well: W, S, O }\end{array}$ & No discussion \\
\hline $\begin{array}{l}\text { Dale and others, } \\
1999\end{array}$ & RSR Smelter in Dallas & W, S, O & $\begin{array}{l}\text { Slower rebound within } 2 \text { miles of } \\
\text { the site compared to other areas }\end{array}$ \\
\hline $\begin{array}{l}\text { Gayer and } \\
\text { others, } 2000\end{array}$ & $\begin{array}{l}\text { Seven NPL sites \& non-NPL } \\
\text { sites in Grand Rapids, MI }\end{array}$ & Many sites & No discussion \\
\hline $\begin{array}{l}\text { Kiel and Zabel, } \\
2001\end{array}$ & $\begin{array}{l}\text { Industriplex and W\&G Well, } \\
\text { Woburn, MA }\end{array}$ & $\begin{array}{l}\text { Industriplex: A, W, S } \\
\text { W\&G Well: W, S, O }\end{array}$ & $\begin{array}{l}\text { Assumed to be zero beyond } 3 \\
\text { miles from the site }\end{array}$ \\
\hline $\begin{array}{l}\text { McClusky and } \\
\text { Rausser, } 2003 \\
\end{array}$ & RSR Smelter in Dallas & $\mathrm{W}, \mathrm{S}, \mathrm{O}$ & $\begin{array}{l}\text { Price premium for distance flattens } \\
\text { out after } 2.6 \text { miles }\end{array}$ \\
\hline $\begin{array}{l}\text { Deaton and } \\
\text { Hoehn, } 2004\end{array}$ & $\begin{array}{l}\text { Barrels, Inc., and Motor } \\
\text { Wheel, Lancing, MI }\end{array}$ & $\begin{array}{l}\text { Barrels, Inc: Not } \\
\text { available } \\
\text { Motor Wheel: W, S }\end{array}$ & $\begin{array}{l}\text { No assumptions on maximum } \\
\text { distance effect }\end{array}$ \\
\hline $\begin{array}{l}\text { Chattopadhyay } \\
\text { and others, } 2005\end{array}$ & Waukegan Harbor, IL & S, W & $\begin{array}{l}\text { Distance effect is assumed to } \\
\text { vanish after } 5 \text { miles }\end{array}$ \\
\hline $\begin{array}{l}\text { Kiel and } \\
\text { Williams, } 2007\end{array}$ & 57 NPL sites in 20 counties & Many sites/media & Assumed to be 3 miles \\
\hline $\begin{array}{l}\text { Nelson and } \\
\text { others, } 1992\end{array}$ & $\begin{array}{l}\text { Landfill (non-hazardous) in } \\
\text { Minneapolis }\end{array}$ & Not an NPL site & 2.5 miles \\
\hline $\begin{array}{l}\text { Smolen and } \\
\text { others, } 1992\end{array}$ & $\begin{array}{l}\text { "Envirosafe Landfill”, } \\
\text { Toledo, OH }\end{array}$ & Not an NPL site & $\begin{array}{l}\text { No effect of waste site on prices } \\
\text { for "greater than } 5.75 \text { m" range. }\end{array}$ \\
\hline $\begin{array}{l}\text { Thayer and } \\
\text { others, } 1992\end{array}$ & $\begin{array}{l}\text { Waste (hazardous \& non- } \\
\text { hazardous) sites in Baltimore }\end{array}$ & Not an NPL site & $\begin{array}{l}\text { Gradient shifts after } 1 \text { mile and } 4 \\
\text { miles in linear specification and } \\
\text { after } 5 \text { miles in semi-log }\end{array}$ \\
\hline $\begin{array}{l}\text { Hite and others, } \\
2001\end{array}$ & $\begin{array}{l}\text { Four landfills, Franklin } \\
\text { County, OH }\end{array}$ & Not an NPL site & Assumed to be 3.25 miles \\
\hline $\begin{array}{l}\text { Ihlanfeldt and } \\
\text { Taylor, } 2004\end{array}$ & $\begin{array}{l}\text { Hazardous waste sites in } \\
\text { Atlanta }\end{array}$ & Not an NPL site & $\begin{array}{l}\text { Assumed a threshold of } 2 \text { mile } \\
\text { radius from the sites }\end{array}$ \\
\hline
\end{tabular}


Table 2: Descriptive Statistics

\begin{tabular}{|c|c|c|c|c|c|c|c|c|}
\hline & \multicolumn{2}{|c|}{ Block Group } & \multicolumn{2}{|c|}{ Tract } & \multicolumn{2}{|c|}{ Zip Code } & \multicolumn{2}{|c|}{ County } \\
\hline Variable & Mean & Std. Dev. & Mean & $\begin{array}{l}\text { Std. } \\
\text { Dev. }\end{array}$ & Mean & $\begin{array}{l}\text { Std. } \\
\text { Dev. }\end{array}$ & Mean & $\begin{array}{l}\text { Std. } \\
\text { Dev. }\end{array}$ \\
\hline NPL & .2121 & .4089 & .0318 & .1756 & .0220 & .1466 & .0072 & .0845 \\
\hline MSA & .3615 & .4805 & .5225 & .4995 & .8129 & .3900 & .7972 & .4021 \\
\hline Density & .0001 & .0006 & .0004 & .0017 & .0021 & .0046 & .0023 & .0051 \\
\hline Population & 89.1615 & 290.229 & 7.9263 & 12.8373 & 4.3288 & 2.1222 & 1.3575 & .8929 \\
\hline Urbanicity & .4139 & .3159 & .3428 & .4318 & .7779 & .3735 & .7741 & .3928 \\
\hline Manufacturing & .0706 & .0428 & .0708 & .0581 & .0653 & .0415 & .0668 & .0467 \\
\hline Unemployment & .0273 & .0123 & .0263 & .0301 & .0300 & .0278 & .0295 & .0307 \\
\hline Black & .0874 & .1443 & .0712 & .1628 & .1361 & .2360 & .1317 & .2441 \\
\hline Hispanic & .0842 & .1863 & .0648 & .1494 & .1260 & .2122 & .1229 & .2170 \\
\hline Income & 34.7306 & 9.3972 & 40.0297 & 17.5493 & 43.7907 & 21.9678 & 44.2645 & 22.8493 \\
\hline No. of obs. & \multicolumn{2}{|c|}{209,899} & \multicolumn{2}{|c|}{66,000} & \multicolumn{2}{|c|}{40,844} & \multicolumn{2}{|c|}{3,376} \\
\hline
\end{tabular}

Variable descriptions:

NPL - Dummy variable taking a value of 1 if areal unit contains at least one NPL site

MSA - Dummy variable taking a value of 1 if areal unit is in or abuts a metropolitan statistical area

Density - Population density of areal unit, measured as total population divided by area (in $\mathrm{m}^{2}$ )

Population - Total population (in 1000s) of areal unit

Urbanicity - Share of total population that is classified as "urban population" in areal unit

Manufacturing - Share of employed population working in manufacturing jobs in areal unit

Unemployment - Unemployment rate in areal unit

Education - Share of total population in areal unit who have graduated high school

Housing Value - Median housing value (in \$1000s) in areal unit

Black - Share of population identifying self as black or African American or Negro as primary racial classification in areal unit

Hispanic - Share of population identifying self as Hispanic or Latino in areal unit, not mutually exclusive with Black

Income - Median household income (in \$1000s) in areal unit 
Table 4: South Cavalcade Environmental Injustice Results

\begin{tabular}{lcc|cc}
\hline & \multicolumn{2}{c}{ Difference in Means ${ }^{\mathrm{a}}$} & \multicolumn{2}{c}{ Logit Analysis } \\
\cline { 2 - 5 } & Block Group & Tract & Block Group & Tract \\
\hline Percent Black & $11.7(6.6)$ & $12.5(4.3)$ & $1.84(4.27)$ & $1.35(1.58)$ \\
Percent Hispanic & $22.0(12.8)$ & $20.1(7.4)$ & $2.98(6.76)$ & $2.60(3.00)$ \\
Median Income (\$) & $21.8(12.5)$ & $21.1(7.7)$ & $-.05(-5.75)$ & $-.07(-3.70)$ \\
\hline
\end{tabular}

${ }^{a}$ Positive difference indicates injustice.

Numbers in parenthesis represent t- or z-statistics as applicable 
Table 5: Summary of EJ Results across Scales, Media

\begin{tabular}{|c|c|c|c|c|c|}
\hline Sample & Variable & County & Zip Code & Tract & Block Group \\
\hline \multirow{3}{*}{ Full } & Black & .901 & $.846^{* * *}$ & $.891^{* * *}$ & $.870^{* * *}$ \\
\hline & Hispanic & $-1.393 *$ & $.845^{* * *}$ & $1.297 * * *$ & $1.158^{* * *}$ \\
\hline & Income & .015 & -.002 & $-.010 * * *$ & $-.010 * * *$ \\
\hline \multirow{3}{*}{ Air } & Black & .623 & .336 & $1.058 * * *$ & $.692 * *$ \\
\hline & Hispanic & $-3.049 * *$ & $1.459 * * *$ & $1.816^{* * *}$ & $.872 *$ \\
\hline & Income & .010 & .001 & $-.008 * *$ & -.005 \\
\hline \multirow{3}{*}{ Water } & Black & .761 & $.743^{* * *}$ & $.943 * * *$ & $.627 * * *$ \\
\hline & Hispanic & $-1.739 * *$ & $.882 * * *$ & $1.215^{* * *}$ & .367 \\
\hline & Income & .010 & -.002 & $-.011 * * *$ & $-.007 * * *$ \\
\hline \multirow{3}{*}{ Soil } & Black & .598 & $0.904 * * *$ & $.939 * * *$ & $.670 * * *$ \\
\hline & Hispanic & $-2.336 * *$ & $.864^{* * *}$ & $1.272 * * *$ & $.451^{*}$ \\
\hline & Income & .007 & -0.002 & $-.011 * * *$ & $-.006 * * *$ \\
\hline \multirow{3}{*}{ Other } & Black & $1.906^{* *}$ & $.952 * *$ & $1.081^{* * *}$ & $.795^{* * *}$ \\
\hline & Hispanic & -1.287 & $1.859 * * *$ & $1.679 * * *$ & $1.029 * *$ \\
\hline & Income & $.024 * *$ & .002 & $-.010 * * *$ & -.001 \\
\hline
\end{tabular}

